Article

\title{
Sensitivity Analysis as a Tool in Environmental Policy for Sustainability: The Case of Waste Recycling Projects in the Republic of Serbia
}

\author{
Ksenija Denčić-Mihajlov ${ }^{1, *(1)}$, Mladen Krstić ${ }^{2}$ and Dejan Spasić ${ }^{1,3}$ (I) \\ 1 Faculty of Economics, University of Niš, Trg kralja Aleksandra Ujedinitelja 11, 18000 Niš, Serbia; \\ dejan.spasic@eknfak.ni.ac.rs or dejan.spasic@ekof.bg.ac.rs \\ 2 Maksi-Co Doo, 18220 Aleksinac, Serbia; mlkrsta@gmail.com \\ 3 Faculty of Economics, University of Belgrade, Kamenička 6, 11000 Belgrade, Serbia \\ * Correspondence: ksenija.dencic-mihajlov@eknfak.ni.ac.rs; Tel.: +381-63-473-606
}

Received: 8 September 2020; Accepted: 24 September 2020; Published: 27 September 2020

\begin{abstract}
Modern consumer society uses an increasing number of products to meet its needs, which become waste after use, thus posing a serious problem that threatens sustainable development. Investment in waste recycling, due to a high level of non-financial benefits, is considered sustainable, especially in the End-of-life Vehicles (ELV) and Waste Electrical and Electronic Equipment (WEEE) recycling areas. The research objective of this paper is to test the sensitivity of the model for sustainable management of recycling projects by applying a cost-benefit analysis (CBA) to investment projects of car and refrigerator recycling in the Republic of Serbia. By testing the key risk factors of the above investment projects within the sensitivity analysis, the main aim is to determine the critical value of these variables in terms of the financial and social acceptability of these investment alternatives. The results obtained indicate that state subsidies have the greatest influence on defining the model of sustainable investment, especially in the field of e-waste recycling. The impact of other factors, the price of secondary raw materials and the social cost of $\mathrm{CO}_{2}$ emissions, is significantly smaller, but should certainly be taken into account when defining the optimal model of sustainable investment.
\end{abstract}

Keywords: sustainable investments; cost-benefit analysis; recycling; ELV; WEEE

\section{Introduction}

According to the Social Investment Forum [1], socially responsible investment (SRI) is an investment process that takes into account both the positive and negative consequences of the investment on society and the environment in the context of rigorous financial analysis. SRI is the business practice of including social and environmental goals in investment decisions [2]. According to Desmadryl [3], SRI is considered sustainable and responsible behavior as it respects the triple bottom line (TBL) concept (people, planet, and profit). In addition to economic indicators, sustainable investment takes into account equally important indicators concerning society and the environment, so that at the same time it takes into account the TBL concept initially introduced by Elkington [4]. That is why SRI around the world has recorded significant growth in recent years, both in relative and absolute terms [5-7]. As Palma-Ruiz et al. indicate, the COVID-19 pandemic environment has additionally stressed the need for the development of corporate social responsibility practices and SRI as a competitive strategy in times of upheaval [8]. Recycling, as a process of processing and reuse of used products with the aim of reducing the harmful effects on the environment and excessive consumption of natural resources, at the same time ensures a sustainable business future. Investment in recycling in a broader socio-economic context can be considered sustainable business behavior that generates a wide range of both financial and non-financial benefits. 
The objective of the paper is to create an optimal investment package in the field of product recycling with special emphasis on the End-of-Life Vehicles (ELV) and Waste Electrical and Electronic Equipment (WEEE) recycling. The aim is to use a cost-benefit analysis (CBA) and sensitivity analysis, to examine the rationality of using subsidies for recycling these two groups of waste in the Republic of Serbia. The contributions of the paper are twofold. Firstly, to the best of our knowledge, this is the first attempt of a comparative analysis of a set of critical factors that determine the financial and economic efficiency of two waste streams recycling in one developing country. This evidence is relevant to decisions aiming at improving the effectiveness of environmental policymakers as well as management in the recycling industry. The main contribution of the paper is applicable to the Republic of Serbia but is relevant to other developing market contexts. Secondly, to be able to better respond to the challenges of sustainable development in the future, we indicate that firms operating in the recycling industry have to identify the significance of the impact of the state subsidies, the price of secondary raw materials, and the social cost of $\mathrm{CO}_{2}$ emissions, and accordingly, to choose the types of strategies that will ensure greater resistance to the uncertainties in these factors and faster recovery if risk situations occur.

Given that the number of cars in the world is increasing every day and that it is estimated that the total number of vehicles produced in the world in 2020 will reach 80 million [9], the issue of their recycling is essential from the aspect of sustainable development. About $5 \%$ of the total generated industrial waste comes from ELV recycling [10], which is also a significant source of raw materials and further emphasizes the importance of proper treatment of used cars. On the other hand, WEEE is one of the fastest-growing waste streams in the world, with an average annual growth rate of 3-5\% [11]. About 50 million tons of this waste is generated annually [12], which at the same time occupies an increasing part of the daily generated household waste. Modern business conditions and the accelerated development of science and technology significantly shorten the lifespan of modern e-products, which become obsolete in a very short time, not so much physically as technologically [13]. All this further highlights the problem of waste management in developed countries, where the waste management system has already been implemented, and especially in less developed countries, where this process is currently taking place [14].

Taking into account all the above, creating an optimal model for sustainable management of recycling projects for these types of products is a serious challenge. Since the recycling process brings a large amount of both financial and non-financial benefits, it is appropriate to apply the cost-benefit analysis in order to examine all the potential of this process. In order to present the process of designing sustainable investment in the Republic of Serbia as comprehensively as possible, we perform a case study of companies dealing with the WEEE recycling process on the one hand, and ELV recycling on the other. Taking into account the similarities, as well as the essential differences in the treatment of these used products, by applying the CBA we determine the degree of acceptability of these investments both from the aspect of investors and from the aspect of society as a whole. The results obtained are further tested using the sensitivity analysis, in order to determine the correlation of CBA parameters and changes in key risk factors, as the main research objective.

In accordance with the research objective and aim, the paper is structured as follows: after the literature review in the second part of the paper, the third part identifies the project business environment, defines ELV and WEEE recycling projects, and describes the research method. In part four, the main research results are presented, along with a discussion of the data obtained. Finally, the concluding considerations identify the key contributions of the paper, the potential research limitations, and the guidelines for future research.

\section{Literature Review}

Given the high intensity of waste generation in the areas of ELV and WEEE, the recycling of these products is the research objective a large number of authors deal with. A comparative overview of waste management systems in the field of ELV and WEEE is not such a common topic, but Rosa and Teresi [15] engage in this field. This paper points to the growing importance of the recycling process of these two 
groups of products since they are a significant source of raw materials, so the introduction of an adequate waste management system is a necessity in every society. Andersson et al. [16] look at the waste management system in the field of recycling of these products from a socio-technological perspective.

ELV recycling is of considerable interest to a large number of authors as end-of-life vehicles are a growing problem for every society in the world. Karagoz et al. [17] systematically present a review of a total of 232 studies dealing with this specific area in the period 2000-2019, noting that the managerial perspective is the primary focus of most studies. The sustainability of ELV recycling, apart from the economic aspect, is also studied from numerous other aspects-technological, sociological, regulatory, environmental, climate, and the like [18-24].

The concept of Integrated Solid Waste Management (ISWM), established in developed countries in the 1990s, seeks to strike a balance between three dimensions of this process: environmental effectiveness, social acceptability, and economic affordability [25]. However, academic research on waste management commonly includes the economic aspects of the CBA, to a lesser extent the environmental aspects of the CBA, and very few social aspects of the CBA [26] (p. 469).

In the field of WEEE, one of the biggest challenges is the creation of an optimal package of financial support from the state, which is essential for maintaining the continuity of the e-waste recycling process. Research in China $[27,28]$ indicates potential problems that arise when official recycling centers do not have sufficient financial support from the state. In such conditions, most of the daily generated e-waste ends up in illegal recycling centers where it is recycled in conditions that are not in accordance with the basic principles of environmental protection. In this context, Lui et al. [27] point to the essential role of subsidies in the recycling of WEEE, especially refrigerators, and test the switching values of this parameter in terms of profitability of the whole process. Their results show that "the use of subsidies can increase the acquisition quantity of used products in the formal sector, but the increase will slow down with higher subsidy" [27].

Some studies address the environmental effects of WEEE recycling. The authors [29,30] prove a positive impact of WEEE recycling on ecology, with special emphasis on this effect and economic savings or profits in the circular economy model as a paradigm of sustainability [31,32]. Xue and $\mathrm{Xu}[33]$ find that, apart from environmental performance, economic feasibility is always taken into account when evaluating electronic waste management activities. They conclude that "the economic evaluation, cost-benefit analysis, or life cycle cost (LCC) combined with life cycle assessment (LCA) could give a comprehensive conclusion".

In the course of analysis, a large number of authors opt for the application of CBA, since it takes into account all benefits and costs in these projects. One of the main sources in this area is the 2014-2020 European guide for the implementation of CBA since the European Commission recommends applying this analysis when analyzing projects in the field of recycling [34]. In the field of CBA of ELV recycling, authors often point out that the car market has a large number of vehicles that are close to the recycling phase, most of them not going through legal recycling flows [35]. Furthermore, some indicate the high importance of subsidies although the profitability of the whole process is satisfactory [36]. Some authors suggest different subsidy rates according to the area of treatment in order to improve the use of stored material from untreated ELVs [37]. In addition to government subsidies, value-added tax and a deposit-refund system are included in the CBA [38]. Due to the complexity of used car components and their individual impact on recycling sustainability, some authors, for example, analyze the range of CBA of ELV glazing recycling [39].

Similarly, especially due to the fact that WEEE includes a large number of different devices, some authors opt for CBA applicability in one or several e-devices. For example, Gurita and Bongaerts [40] investigate the issues of CBA of mobile phone and smart phone recycling. Zadmehr et al. [41] prove the cost-effectiveness of WEEE recycling by applying CBA on the example of one city.

Sensitivity analysis, as an integral part of CBA, is also used in other papers dealing with WEEE treatment. For example, Rigamonoti et al. [42] apply sensitivity analysis to the WEEE life cycle (Life-Cycle-Assessment) and its impact on the environment. They specifically analyze the treatment of five groups of e-products, including a group of large household appliances, such as refrigerators. 
The sensitivity analysis tests how different sets of so-called characterization factors in metals affect the final results of the analysis, that is, the impact on the environment. D'Adamo et al. [43] also apply sensitivity analysis, focusing on the recycling of waste printed circuit boards (WPCB) from different groups of e-devices. They test the profitability of this investment using sensitivity analysis and addressing changes in key risk factors related to stock market prices of metals that occur as a product of the recycling process.

Wan et al. [44] apply sensitivity analysis in the field of ELV and indicate the high importance of state subsidies in the field of ELV recycling, which will be the basis for a comparative analysis of the research results in this paper. They apply sensitivity analysis to car recycling and analyze the impact of the number of state subsidies on the volume of recycling and its profitability. Taking into account the costs of procurement, treatment, and transportation of used cars, Wan et al. [44] point to the need to further stimulate financially this process. They test the optimal amount of financial support by using sensitivity analysis. Zhou et al. [45] also use sensitivity analysis in the field of ELV recycling, to test different combinations of critical parameters, that is, establish the potential scenario and analyze the results obtained.

\section{Materials and Methods}

\subsection{Socio-Economic and Institutional Environment in the Republic of Serbia}

The development of the recycling industry today is a necessity for both developed and less developed and developing countries like the Republic of Serbia. Modern business conditions have imposed the need to dispose of large amounts of generated waste, since the current business model in the world still dominantly relies on the linear concept, while the development of circular models is still in its infancy. In transition economies, due to the low living standard of the population, the purchase of new products is symbolic, so that a large part of the products in use is very close to or at the very end of the useful life, especially in the field of e-products and cars.

In this regard, there is a significant raw material base and great potential for the development of the recycling industry in the Republic of Serbia. According to the official data of the Environmental Protection Agency, the import of various types of e-products is stable over the years, and in the period 2013-2018 ranged from $9199.82 \mathrm{t}$ to $12,643.60 \mathrm{t}$. On the other hand, car import records a slight increase, so that in the period 2013-2018 the imported cars varied between 75,040.92 $\mathrm{t}$ and as much as $282,709.20 \mathrm{t}$ [46] (p. 34). Data on worn-out products ready for the recycling process is far more important for the recycling industry, but there are certain problems in this segment. Specifically, the sphere of used cars in the Republic of Serbia lacks adequate data on deregistered vehicles, as the basis for determining the potential number of ELVs. Therefore, for the purposes of this analysis, we use a stock projection method, based on statistical data on the total number of registered and newly registered vehicles [47]. Some authors also use the Delphi method for calculating the amount of ELV generated. The application of this method showed that the quantity of ELV generated in the period 2006-2014 in the Republic of Serbia ranges between 33,685 kg and 110,744 kg [48] (pp. 117-119).

Despite the fact that the level of non-financial reporting in Serbia is still low [49], in the field of WEEE recycling, the quantity of products recycled during the year is available, since all companies submit accurate reports, as the basis for obtaining government incentives. These reports are periodically published by the Environmental Protection Agency, and in the period 2011-2018, the quantity of recycled e-products ranged between $7084 \mathrm{t}$ and even $37,004 \mathrm{t}$, with the maximum volume of recycling reached in 2016 [46] (p. 35). The above data clearly indicates that the Republic of Serbia has a significant raw material base for the development of the recycling industry in the field of ELV and WEEE. This will be essential in defining the basic parameters related to the scope of recycling of regional centers for the treatment of these types of waste, which will later be the subject first of CBA, and then sensitivity analysis, in order to determine the optimal model for sustainable investment. 
The legislative framework in the field of waste management of the Republic of Serbia relies on two systemic laws, the Law on Waste Management, the Law on Environmental Protection, and a large number of other bylaws. From the aspect of recycling products that after use become special waste streams, which include used vehicles and e-waste, two rulebooks are especially important. Positive regulations in the field of waste management provide recycling companies with additional financial incentives, which are regulated by the rulebook on harmonized amounts of incentives for reuse, recycling, and the use of certain types of waste [50]. On the other hand, all importers and producers of these products are obliged to pay a fee when placing them on the market, which is regulated by the rulebook on harmonized amounts of fees for the management of special waste streams [51]. These two rulebooks are especially important when defining the total amount of incentives that each recycling company receives for the treatment of certain products.

\subsection{Defining ELV and WEEE Recycling Projects}

In order to perform the CBA of the above investment projects, it is first necessary to perform investment analysis, define sources of financing, determine the appropriate discount rate, and finally make a projection of income and expenditure of projects. Both projects are observed over a period of 10 years. The first two years are reserved for the acquisition of equipment and installation, and in the next period cash flows are discounted and CBA parameters are calculated. A financial CBA is followed by a socio-economic CBA, and finally, a sensitivity analysis is performed in accordance with the identified risk factors. The research follows the methodology of the European Commission for the 2014-2020 program period [34].

Transport costs in the field of recycling play a significant role, so the development of this industry in each country requires larger recycling centers within each region since the centralized deployment of these plants prevents optimal use of resources and maximizing benefits. The structure of investment in these two projects is determined by the recycling needs of these types of products in the region of Southern and Eastern Serbia. Based on the data on recycling in the report of the Environmental Protection Agency [46], and data of recycling companies in the Republic of Serbia, we can define the investment structure for regional recycling centers in the region of southern and eastern Serbia. The structure of investment performed in the first two years in these investment projects is shown in Table 1.

Table 1. Structure of investment $(€)$.

\begin{tabular}{ccc}
\hline Investments & ELV Recycling Center & WEEE Recycling Center \\
\hline Facilities & 160,000 & $1,120,000$ \\
\hline Equipment & 669,000 & $2,249,000$ \\
\hline Land & 10,000 & 30,000 \\
\hline Feasibility study & 1000 & 1000 \\
\hline Permanent working capital & 118,000 & 141,000 \\
\hline Total & 958,000 & $3,541,000$
\end{tabular}

The amount of investment in a WEEE recycling center is higher, as the process of recycling these types of products is more complex and requires the engagement of more expensive equipment. In order to ensure the comparability of these two investment projects, the volume of recycling is defined at the level of $8000 \mathrm{t}$ per year for both recycling centers, so that the costs and benefits of the recycling process will be analyzed on the same sample of used products. In addition to investment in fixed assets, it is important to point out that for the normal functioning of the recycling process, a certain amount of permanent working capital is necessary to include in the total investment. Unlike the car group, which is quite homogeneous, the WEEE group consists of as many as 10 categories [52] (Annex I). Due to the complexity of the comparative analysis of the entire WEEE group, here we 
opt for refrigerator recycling. This group is especially important from the aspect of generating a high amount of socio-economic benefits, since it contains a high amount of harmful gases, making it suitable for analysis. In addition, it is necessary to define the revenue structure for a recycling volume of $8000 \mathrm{t}$. Considering that the average weight of a vehicle is around $800 \mathrm{~kg}[53,54]$, while the average weight of a refrigerator is $54 \mathrm{~kg}$ [55], this requires a recycling volume of 10,000 cars or 148,148 units of refrigerators per year. All revenues can be divided into one part related to the sale of secondary raw materials (Tables 2 and 3) and another part, which includes state subsidies for recycling (revenues from sale of secondary raw materials are presented in Tables S1, S3, S5 and S7, please see in Supplementary Materials).

Table 2. Revenues from the sale of secondary raw materials: the case of ELV recycling.

\begin{tabular}{cccccc}
\hline $\begin{array}{c}\text { Secondary } \\
\text { Raw Materials }\end{array}$ & $\begin{array}{c}\text { Quantity Per } \\
\text { ELV (t) }\end{array}$ & $\begin{array}{c}\text { Recyclability } \\
\mathbf{9 0 \%} \mathbf{( t )}\end{array}$ & Price $\boldsymbol{\epsilon} / \mathbf{t}$ & Per ELV & For 10.000 ELVs \\
\hline Iron & 0.626 & 0.563 & 226 & 127.33 & $1,273,284$ \\
\hline Aluminum & 0.041 & 0.037 & 1270 & 46.75 & 467,487 \\
\hline Copper & 0.008 & 0.007 & 5100 & 36.72 & 367,200 \\
\hline Tires & 0.026 & 0.023 & 40 & 0.93 & 9324 \\
\hline Batteries & 0.010 & 0.009 & 800 & 7.2 & 72,000 \\
\hline Total & \multicolumn{2}{c}{${ }^{1}[53,54]}$.
\end{tabular}

Table 3. Revenues from the sale of secondary raw materials: the case of WEEE recycling.

\begin{tabular}{cccccc}
\hline $\begin{array}{c}\text { Secondary } \\
\text { Raw Materials }\end{array}$ & $\begin{array}{c}\text { Quantity Per } \\
\text { Refrigerator (kg) }\end{array}$ & After Grinding (kg) & Price $\mathbf{\epsilon} / \mathbf{t}$ & \multicolumn{2}{c}{ Revenue (€) } \\
\cline { 5 - 6 } & & & $\begin{array}{c}\text { Per } \\
\text { Refrigerator }\end{array}$ & $\begin{array}{c}\text { For 148,148 } \\
\text { Refrigerators }\end{array}$ \\
\hline Iron & 34.20 & 17.62 & 226 & 3.98 & 589,943 \\
\hline Aluminum & 2.25 & 1.09 & 1270 & 1.38 & 205,081 \\
\hline Copper & 0.31 & 0.09 & 5100 & 0.46 & 68,000 \\
\hline Stainless steel & 0.01 & 0.01 & 975 & 0.01 & 1445 \\
\hline Plastic & 6.83 & 3.33 & 320 & 1.07 & 157,866 \\
\hline Total & & & 6.90 & $1,022,335$ \\
\hline
\end{tabular}

As the previous tables show, only secondary raw materials that have a higher share in products subject to recycling are taken into account in the revenue structure. Also, due to the more complex and expensive process of refrigerator recycling, there are certain losses of the substance after the grinding process in special chambers without the presence of oxygen.

As a result of the specifics of the recycling process and the very complex treatment of e-waste, in particular, the profitability of this process largely depends on external support in the form of subsidies. In the case of car recycling, this amount of state support is symbolic, while in the field of refrigerator recycling it is significant and in the revenue structure of these companies, it reaches as much as 70\% [56] (p. 195). Recycling subsidies are defined by the rulebook on harmonized amounts of incentives for reuse, recycling, and use of certain types of waste [50], but, in practice, it happens that the state pays recycling companies lower amounts than those guaranteed by the rulebook, with deviations in payment dynamics. That is why recycling subsidies have been identified as one of the key risk factors in terms of recycling industry development in the Republic of Serbia [56]. With this in mind, it is more rational to take the amount of fees paid when placing e-products on the market as the amount of incentives, which is defined by the rulebook on harmonized amounts of fees for the management 
of special waste streams [51]. Part of the revenue from car recycling can also be generated through the sale of car parts for reuse, as one of the principles of the recycling process is to reuse all items wherever possible.

After outlining income, the CBA requires the definition of the current expenses that occur during the recycling process. As Table 4 shows, the WEEE recycling process requires more significant electricity consumption as well as the use of special gases, such as nitrogen. Unlike secondary raw materials in ELV recycling that do not require special treatment, in WEEE or refrigerator recycling, it is very important to collect all the freon contained in refrigeration equipment, store it adequately, and forward it for further treatment abroad. The project expenses are presented in project income statement (please see Tables S1, S3, S5 and S7 in Supplementary Materials.

Table 4. Expense structure.

\begin{tabular}{ccc}
\hline Expense Structure & ELV Recycling $(\boldsymbol{\epsilon})$ & Refrigerator Recycling $(\boldsymbol{\epsilon})$ \\
\hline Costs of direct material & $1,420,000$ & $1,694,915$ \\
\hline Labor costs (gross) & 154,800 & 309,600 \\
\hline Costs of investment maintenance & 100,000 & $110,000-130,000$ \\
\hline Fuel and lubricant costs & 140,000 & 100,000 \\
\hline Transport, forwarding, and radiology costs & 76,000 & \\
\hline Waste disposal costs & 1500 & 75,000 \\
\hline Electricity costs & 30,000 \\
\hline Costs of gas-nitrogen & 300,000 \\
\hline Transport costs & 70,000 \\
\hline Freon disposal costs & $28,000-365,350$ \\
\hline Depreciation costs & $4000-104,350$ & \\
\hline
\end{tabular}

After defining the amount of initial investment, basic income, and the expenses of recycling projects, it is required to define the discount rate. The financial analysis does this using the weighted average cost of capital, which, depending on the relationship between the level of borrowed funds and own funds, as well as their prices, determines the average price or discount rate. In specific examples, about $25 \%$ of the estimated capital is obtained from own sources of financing, while the rest within the financial CBA is provided through a subsidized loan. The combination of these two sources of financing forms the discount rate within ELV recycling at the level of $3.48 \%$, while in the case of refrigerator recycling this rate is $3.32 \%$ [56] (pp. 144-149). After defining the basic parameters, we can conduct a CBA, in order to examine how the above investment projects behave within a financial analysis based on the perspective of investors, and then within a socio-economic analysis to determine the contribution of these projects to the benefits for society as a whole.

The European Commission has established a unique methodology according to which all investment projects are tested. The objective of CBA in the past has usually been large infrastructure projects whose investor was most often the state. In the last guide for the implementation of CBA, in addition to these infrastructure projects, projects in the field of waste management or recycling are also included, and a special chapter is dedicated to them [34] (pp. 158-170). All projects that are the subject of the CBA go through the same procedure that first determines the socio-economic and institutional environment, followed by the definition of objectives and project identification. For projects in the field of recycling, the basic goals are usually defined as the reduction of pollution, savings in energy consumption and use of raw materials, and others. Before moving on to the financial and socio-economic analysis that is the most important part of the CBA, projects must first go through a phase of technical feasibility and environmental sustainability. An integral part of the CBA analysis is risk assessment through sensitivity analysis, which is especially important here due to the definition 
of the optimal model for sustainable investment management. In the process of the sensitivity analysis, we first identify the key risk factors, test their impact on CBA parameters, and finally establish a model for sustainable financing.

\section{Results and Discussion}

\subsection{Financial Cost-Benefit Analysis}

In accordance with the EU methodology related to the implementation of CBA in investment projects, we first perform financial analysis and later make certain adjustments to the model in order to conduct a socio-economic analysis. Financial Net Present Value (FNPV) is a discount method used in CBA to determine the current value of all future cash flows generated by a project, including the initial capital investment, such as in Equation (1):

$$
\mathrm{FNPV}=\sum_{\mathrm{t}=0}^{\mathrm{n}} \frac{\mathrm{NCF}_{\mathrm{t}}}{(1+\mathrm{r})^{\mathrm{t}}}
$$

where $\mathrm{NCF}_{\mathrm{t}}$ is net cash inflow-outflows during a single period $t$; $r$ is the discount rate; $t$ is the number of time periods.

The Financial Internal Rate of Return on investment (FRR) is defined as the discount rate that produces a zero FNPV. It is calculated as a solution to the following Equation (2):

$$
0=\sum_{\mathrm{t}=0}^{\mathrm{n}} \frac{\mathrm{NCF}_{\mathrm{t}}}{(1+\mathrm{FRR})^{\mathrm{t}}}
$$

Having identified investment projects, sources of financing, cost and revenue structure, and calculated the discount rate, we calculate the CBA criteria (Table 5). Financial CBA criteria calculation is based on economic flow for both projects (please see Tables S2 and S4 in Supplementary Materials).

Table 5. Financial CBA criteria.

\begin{tabular}{ccc}
\hline Elements & ELV Recycling Center & Refrigerator Recycling \\
\hline Present value of project benefits & $17,855,866 €$ & $27,967,426 €$ \\
\hline Present value of projects costs & $16,687,116 €$ & $27,695,291 €$ \\
\hline Financial net present value (FNPV) & $1,168,750 €$ & $272,135 €$ \\
\hline Financial internal rate of return (FRR) & $22.34 \%$ & $4.60 \%$ \\
\hline Benefits/costs ratio (B/C) & 1.070 & 1.010 \\
\hline
\end{tabular}

The financial CBA has unequivocally indicated the acceptability of both investment projects from an investor perspective. Specifically, all indicators in this analysis are positive and the implementation of these projects brings investors a profit. Although in both cases the volume of recycling is $8000 \mathrm{t}$, we see that the present value of the benefits of the ELV recycling project is lower compared to the value recorded by another investment project, but the amount of costs is also significantly lower. On the benefit side, the difference is primarily due to a significant share of subsidies in the revenue structure, while a significantly higher amount of costs is a result of the very complex and expensive process of treatment of used refrigerators. If the amounts of FNPV are compared, this advantage goes to car recycling, since despite the modest amount of subsidies for ELV recycling, the total amount of net benefits is higher. Since car recycling requires fewer resources, with equipment being cheaper than refrigerator recycling, it has the obvious advantage of comparing financial rates of return. 


\subsection{Socio-Economic Analysis}

In accordance with the official guide of the European Commission for the 2014-2020 program period, for the transition from financial to socio-economic analysis, the following adjustments are made:

- Fiscal corrections;

- Conversion from market to shadow prices;

- Evaluation of non-market benefits [34] (p. 54).

Fiscal adjustments refer to the exclusion of all types of taxes, subsidies, and other fiscal expenditures, both on the benefit and on the cost side. The main reason for this lies in the fact that all fiscal levies and incentives do not create new value, but only redistribute existing ones. In the above investment projects, the adjustments will mostly include costs of salaries expressed in the net amount within this analysis, the subsidized loan will be replaced by the more expensive commercial loan, while the most significant adjustment will be on the income side by eliminating recycling subsidies. The latter is mostly reflected in the refrigerator recycling project since these subsidies make up the majority of the revenue structure.

Conversion from market to shadow prices allows quantities taken from less developed markets to be replaced by those coming from more competitive markets. In this part, the most significant adjustment tackles labor costs, so this will significantly increase these expenses, and thus the total costs.

The most important adjustment in investment projects in the field of recycling is related to non-financial benefits, as they need to be translated into monetary units, and thus, included in the analysis. At the same time, this is the biggest challenge in this analysis, since most of the benefits of recycling projects are manifested through non-financial benefits, which are not as transparent as the financial benefits.

The recycling process achieves multiple benefits for society on several grounds. First of all, there are significant energy benefits, since the production of iron and aluminum products use much less energy when recycled raw materials are used than when ores from primary production are used as inputs. Research has shown that when recycling scrap iron per ton of metal, there are savings in the emission of $1.69 \mathrm{t}$ of $\mathrm{CO}_{2}$ gas, or $17.7 \mathrm{GJ}$ of energy, while recycling aluminum per ton saves a total of $9.5 \mathrm{t}$ of $\mathrm{CO}_{2}$ or $86.2 \mathrm{GJ}$ of energy [57] (pp. 2448-2449). In order to express energy savings through $\mathrm{CO}_{2}$ emissions, for easier quantification, we assume that about $70 \%$ of electricity in the Republic of Serbia comes from burning coal [58], which indirectly creates additional $\mathrm{CO}_{2}$ emissions. The European Commission estimates that each $\mathrm{KWh}$ produced in thermal power plants releases about $95 \mathrm{~kg}$ of $\mathrm{CO}_{2}$ [34] (p. 168). It prescribes a social emission cost value of $\mathrm{CO}_{2 \mathrm{e}}\left(1 \mathrm{~kg} \mathrm{CO}=1 \mathrm{~kg} \mathrm{CO} \mathrm{CO}_{2 \mathrm{e}}\right)$ at the level of $34 € / t$ during 2020 in order to constantly increase this value by $1 € / t$ each year until 2030 to compensate increased pollution [34] (p. 63). Quantification of all benefits in car recycling is shown in Table 6. Energy savings and $\mathrm{CO}_{2}$ emission savings are presented in Tables S5 and S7, please see in Supplementary Materials.

Since the recycling of refrigerators due to the need to dispose of harmful gases (freon) brings significant savings to society as a whole, it is now necessary to quantify these benefits using a similar methodology. Specifically, the recycling of one average refrigerator saves in the emission of harmful gases of $0.72 \mathrm{t}$ of $\mathrm{CO}_{2}$ gas, while at the same time it saves approximately $1.5 \mathrm{GJ}$ of energy [59] (pp. 9-10). The savings in refrigerator recycling are identified in Table 7. 
Table 6. Quantification of savings in $\mathrm{CO} 2$ emissions and energy consumption in the process of car recycling.

\begin{tabular}{|c|c|c|c|c|}
\hline \multirow[t]{2}{*}{ Elements } & \multicolumn{2}{|c|}{$\begin{array}{c}\mathrm{CO}_{2} \text { Emissions from Production } \\
\text { (t } \mathrm{CO}_{2} / \mathrm{t} \text { Metal) }\end{array}$} & \multicolumn{2}{|c|}{$\begin{array}{c}\text { Energy Consumption in Metal } \\
\text { Production (GJ/t Metal) }\end{array}$} \\
\hline & Al & $\mathrm{Fe}$ & Al & $\mathrm{Fe}$ \\
\hline Savings per ton of metal & 9.5 & 1.69 & 86.2 & 17.7 \\
\hline Savings per vehicle & 0.388 & 1.058 & 3.525 & 11.080 \\
\hline For 10.000 vehicles & 3886 & 10,580 & 35,256 & 110,802 \\
\hline $1 \mathrm{GJ}=277,78 \mathrm{Kwh}$ & & & $9,793,356$ & $30,778,580$ \\
\hline $1 \mathrm{Kwh}=0.95 / 1000 \mathrm{tCO}_{2} \mathrm{e}$ & & & 9304 & 29,240 \\
\hline $70 \%$ of electricity from coal & & & 6513 & 20,468 \\
\hline $1 \mathrm{t} \mathrm{CO}_{2}=34 €$ & 132,107 & 359,700 & 221,428 & 695,903 \\
\hline $\begin{array}{l}\text { Savings in the emission of } \\
\qquad \mathrm{CO}_{2}(€)\end{array}$ & \multicolumn{2}{|c|}{491,807} & & \\
\hline Savings in energy $(€)$ & & & \multicolumn{2}{|c|}{917,331} \\
\hline
\end{tabular}

Table 7. Quantification of savings in $\mathrm{CO}_{2}$ emissions and energy consumption in the process of refrigerator recycling.

\begin{tabular}{|c|c|c|}
\hline Elements & $\begin{array}{l}\text { Savings in Gas Emissions } \\
\text { (t } \mathrm{CO}_{2} \mathrm{e} / \text { Refrigerator Unit) }\end{array}$ & $\begin{array}{c}\text { Savings in Energy } \\
\text { (GJ/Refrigerator Unit) }\end{array}$ \\
\hline Savings per unit & 0.72 & 1.5 \\
\hline For 148,148 units & 106,667 & 222,222 \\
\hline $1 \mathrm{GJ}=277.78 \mathrm{Kwh}$ & & $61,728,827$ \\
\hline $1 \mathrm{Kwh}=0.95 / 1000 \mathrm{tCO}_{2}$ & & 58,642 \\
\hline $70 \%$ of electricity from coal & & 41,050 \\
\hline $1 \mathrm{tCO} 2=34 €$ & $3,626,663$ & $1,395,689$ \\
\hline Savings in $\mathrm{CO}_{2}(€)$ & $3,626,663$ & \\
\hline Savings in energy $(€)$ & & $1,395,689$ \\
\hline
\end{tabular}

After the initial adjustments, it is necessary to determine the discount rate at which in this case we will discount all socio-economic benefits and costs. According to the recommendation of the European Commission, here we use a social discount rate, defined at the level of 5\% [34] (p. 55). Since all adjustments to the model have been made, it is now possible to move from financial to socio-economic analysis, that is, from the perspective of investors to the perspective of society as a whole. The basic criteria of socio-economic analysis (Table 8) are Economic Net Present Value-ENPV (the difference between discounted total social benefits and costs), and Economic Internal Rate of Return-ERR (the rate that produces a zero ENPV) (Table 8). Economic CBA criteria calculation is based on socio-economic flow for both projects (please see Tables S6 and S8 in Supplementary Materials).

A comparative review of indicators in both investment projects leads to the conclusion that the adjustments made significantly contribute to the increase in both benefits and project costs. However, the dynamics of benefit growth are more intense, to bring an increase in the economic net present value (ENPV). Nominal growth of ENPV is more pronounced in refrigerator recycling, but since this increase comes with higher investments compared to those in the car recycling center, the economic rate of return is lower, $57 \%$, compared to $113 \%$ in ELV recycling, which is in any case above the rate of the investment criterion. Although there has been a significant increase in labor costs due to the application of conversion factors, this growth has been depreciated by an even more intense increase in benefits in the name of significant recycling benefits. This is especially pronounced in the recycling of refrigerators, 
since the very demanding and expensive treatment of these products allows the generation of a huge amount of benefits for society as a whole, so, from this aspect, this investment is socially justified.

Table 8. Economic CBA criteria.

\begin{tabular}{ccc}
\hline Elements & ELV Recycling Center & Refrigerator Recycling Center \\
\hline Present value of project benefits & $26,956,606 €$ & $47,181,611$ \\
\hline Present value of projects costs & $17,689,819 €$ & $30,822,644$ \\
\hline Economic net present value (ENPV) & $9,266,787 €$ & $16,358,967$ \\
\hline Economic internal rate of return (ERR) & $113 \%$ & $57 \%$ \\
\hline Benefits/costs ratio (B/C) & 1.524 & 1.531 \\
\hline
\end{tabular}

\subsection{Sensitivity Analysis—Results and Discussion}

Sensitivity analysis is an integral part of the CBA and can be used when testing models for sustainable investment management in the field of recycling. It enables the identification of the so-called "critical" variables that have a significant impact on the CBA criteria. Variations of these variables lead to significant changes in the value of the NPV parameter, but also other CBA parameters. The testing of these variables is carried out in two phases. We first test how changes in variables, which at the same time have the highest degree of correlation with the CBA criteria, affect the value of these criteria. Within the second phase of sensitivity analysis, the so-called switching values of critical variables are determined, within which projects are acceptable both from the aspect of investors and from the perspective of society as a whole [34] (pp. 67-68).

The subsidy policy is especially evident in the recycling of refrigerators since state subsidies make up a significant part of the revenue structure. In addition to these two factors, it is interesting to determine how the criteria of CBA change in relation to the change in the price of the social cost of $\mathrm{CO}_{2}$, and what are the limits of change of this parameter while the projects are still acceptable for implementation. In this regard, sensitivity analysis will go in two directions. We will first test how changes in the variables identified as critical (sales price of scrap iron, amount of government subsidies, and social cost of $\mathrm{CO}_{2}$ emissions) affect net present value generation in both financial and socio-economic analysis. After that, the so-called switching values are determined, that is, we calculate the maximum amount of changes of critical variables, while the investment project is acceptable for implementation.

With reference to some models of sensitivity analysis of the authors already cited in the Literature Review [42-45], we create a model for ELV and refrigerator recycling applicable in the Republic of Serbia. We test how changes in critical variables lead to changes in the CBA criteria, and what are the limits of changes in these critical variables at which projects are still acceptable for implementation (Tables 9 and 10).

Table 9. Sensitivity analysis results.

\begin{tabular}{|c|c|c|c|c|c|c|}
\hline \multirow{3}{*}{ Variable } & \multirow{3}{*}{ Initial Value } & \multicolumn{5}{|c|}{ Scope of Change in the Criteria Values } \\
\hline & & \multirow[b]{2}{*}{ Change } & \multicolumn{2}{|c|}{ ELV Recycling } & \multicolumn{2}{|c|}{ Refrigerator Recycling } \\
\hline & & & FNPV & ENPV & FNPV & ENPV \\
\hline $\begin{array}{l}\text { The price of scrap } \\
\text { iron }\end{array}$ & $226 € / t$ & $-5 \% /+5 \%$ & $-36 \% /+36 \%$ & $-5 \% /+5 \%$ & $-72 \% /+72 \%$ & $-1 \% /+1 \%$ \\
\hline $\begin{array}{c}\text { The value of state } \\
\text { subsidies }\end{array}$ & $3.16 € / \mathrm{t} 305.23 € / \mathrm{t}$ & $-10 \% /+10 \%$ & $-1 \%-+1 \%$ & Not applicable & $-600 \% /+600 \%$ & Not applicable \\
\hline $\begin{array}{l}\text { Social cost of } \\
\mathrm{CO}_{2} \text { emissions }\end{array}$ & $34 € / \mathrm{t}$ & $-3 \% /+3 \%$ & Not applicable & $-3 \% /+3 \%$ & Not applicable & $-6 \% /+6 \%$ \\
\hline
\end{tabular}


Table 10. Switching values in the sensitivity analysis.

\begin{tabular}{cccc}
\hline Variable & Criteria & ELV Recycling & Refrigerator Recycling \\
\hline \multirow{2}{*}{ The price of scrap iron } & FNPV & $-13.89 \%$ & $-6.90 \%$ \\
\cline { 2 - 4 } & ENPV & Not applicable & Not applicable \\
\hline The value of & FNPV & Not applicable & $-1.67 \%$ \\
\cline { 2 - 4 } state subsidies & ENPV & Not applicable & Not applicable \\
\hline Social cost of & FNPV & Not applicable & Not applicable \\
$\mathrm{CO}_{2}$ emissions & ENPV & $-93.89 \%$ & $-46.51 \%$ \\
\hline
\end{tabular}

The stock market price of scrap iron is very sensitive to changes in the world economy, so recycling companies of low economic strength must adapt to these circumstances without the possibility of influencing them. The practice has shown that this value can oscillate significantly in a short period of time, but we take changes to be $5 \%$ here. We notice that even such small changes have a significant impact on the net present value, which is most pronounced within the financial CBA in refrigerator recycling. The high share of revenues from the sale of scrap iron in the structure of total revenues from refrigerator recycling causes a change in FNPV of as much as $72 \%$ (36\% in case of ELV recycling). Within the socio-economic analysis, the intensity of these changes in FNPV ranges between 1\% and 5\%, since within this analysis, most of the revenues related to non-financial benefits from recycling.

State subsidies are a very important factor in terms of the development of the recycling industry in the Republic of Serbia. Their role is especially emphasized in the recycling of refrigerators since the sensitivity analysis shows that changes in this factor by $10 \%$ lead to changes in FNPV of as much as $600 \%$. On the other hand, in ELV recycling, the impact of this factor is far more modest, since its share in the structure of total revenues is relatively smaller. Within the socio-economic analysis, due to fiscal adjustments, the number of subsidies is excluded from investment projects, so in that part, there is no impact on the CBA criteria.

Other countries have also recognized the importance of the system of the recycling process subsidizing, so they support this process in accordance with their capabilities. Thus Japan, in the field of car recycling beginning from 2005, started charging a special fee when buying new cars, which is the basis for paying incentives to recyclers [60]. This way of financing the recycling process is far fairer since the fee is paid by persons who generate potential waste-vehicle owners, unlike in the Republic of Serbia where this fee is paid from the state budget from all taxpayers, regardless of whether they own a car. Subsidizing the WEEE recycling process has also become a practice in other countries. One of the leaders, both in terms of technology and e-waste disposal, is China. In 2012, China introduced financial incentives to recycling companies in the WEEE area, resulting in an intensification of this process. First, it imposed a fee that all manufacturers and importers of e-products pay into a special fund, these funds are later transferred to recycling companies according to their performance [61]. The Republic of Serbia faces challenges in this regard since the system of e-waste recycling did not exist until 2011. The waste that has been stored for years together with used products that are now entering the recycling process is currently being recycled. That is why the amount of recycled raw materials is several times higher than the number of products sold on the market [46]. Therefore, a significant part of subsidies is financed from the budget, and less from the fees charged to producers or importers of e-products.

Recycling investment projects show their full potential within the economic analysis, where a special procedure is used to quantify non-financial benefits into financial ones (Tables 6 and 7). According to the recommendation of the European Commission, a pre-defined initial value of the social cost of $\mathrm{CO}_{2}$ gas of $34 € / t$ is used for this procedure, whereby this variable is further increased by $1 € / t$ for each subsequent year. In order to get better acquainted with the real potentials that the recycling process has, we test how changes in the price of this factor affect the parameters, the non-financial benefits within the economic analysis. Sensitivity analysis shows that changes in the price of the social 
cost of $\mathrm{CO}_{2}$ of $3 \%$ cause a change in ENPV within ELV recycling of 3\% also, while within refrigerator recycling, due to higher amount of generated benefits, the intensity of changes is higher and amounts to as much as $6 \%$.

When defining sustainable investment, it is especially important to identify the so-called switching values, as they show the extent to which key variables can be changed while still keeping projects eligible for funding. The determination of the switching value of key variables is given in Table 10.

From the aspect of changes in the price of scrap iron, the ELV recycling project is "more resistant" to changes in this value compared to other recycling projects. Specifically, this project is eligible for financing until the price of scrap iron drops by $13.89 \%$ as opposed to a reduction of $6.90 \%$ in refrigerator recycling. On the other hand, changes in the number of state subsidies for recycling do not affect the eligibility of the ELV recycling project, while in the refrigerator recycling project a reduction of this parameter by more than $1.67 \%$ brings this investment into the zone of ineligibility.

The fact that recycling projects carry a high amount of socio-economic benefits is supported by the result of the sensitivity analysis when testing the price of the social cost of $\mathrm{CO}_{2}$ gas. Specifically, within the economic analysis, it is possible to reduce this parameter by $93.89 \%$, while the ELV recycling project is in the zone of eligibility for financing. Testing of this parameter within the refrigerator recycling project shows a lower degree of tolerance since any reduction in the price of the social cost of $\mathrm{CO}_{2}$ gas that is above $46.51 \%$ is not acceptable from the aspect of project implementation. Although it is unlikely that the price of the social cost of $\mathrm{CO}_{2}$ gas will decrease in the future, since there is a constant trend of increasing pollution in the world from year to year. From the investment point of view, it is good to know the eligibility limits of these projects. Numerous authors identify the socio-economic benefits of the WEEE recycling process. Among them, Menikpura especially emphasizes the benefits in the form of savings in $\mathrm{CO}_{2}$ gas emissions, which are the greatest in the case of refrigerator recycling compared to other e-products that are subject to recycling [62]. Having in mind the significant benefits in the recycling of refrigerators, it is not surprising that the amount of incentives in the Republic of Serbia for this group of products is the largest in relation to other categories of e-waste. This has resulted in a significant increase in the amount of recycled e-products in order to get as close as possible to the level prescribed by Directive 2012/19/EU [63].

\section{Conclusions}

Designing an optimal investment package, that enables the desired profitability and satisfies environmental and social criteria, requires consideration of a large number of factors that affect the recycling process. By examining the basic characteristics of the car, electrical, and electronic device (with special reference to refrigerators) recycling in the Republic of Serbia, the paper points out the key factors that influence business decision-making. Having applied the CBA to specific investment projects, the values of the analysis criteria are first determined both within the financial and economic analysis, and later these results are tested through sensitivity analysis.

Although a large number of factors affect the business of recycling companies in this area, the paper singles out a total of three with the greatest impact on the evaluation criteria. Stock market prices of secondary raw materials, especially scrap iron, have recorded significant oscillations in the past, so it is justified to include this factor in the analysis. Since the share of revenues from the sale of scrap iron is higher in the structure of revenues from refrigerator recycling, it is understandable that this recycling project is more dependent on changes in this parameter. This is undoubtedly shown by the sensitivity analysis, since the switching value in the selling price of scrap iron is $-6.90 \%$ for refrigerator recycling, compared to $-13.89 \%$ for car recycling. This actually means that car recycling, from the aspect of changes in the stock market price of scrap iron, is a more stable project compared to refrigerator recycling since that project has a higher tolerance threshold on this basis.

Subsidizing the recycling process, as a risk factor that affects the development of this industry is also addressed in the paper. The paper confirms the generation of a high amount of socio-economic benefits which justify additional encouragement of this process. The system of subsidizing the recycling process in 
the Republic of Serbia is an important factor that contributes to the development of this industry, especially if we consider the WEEE area. Sensitivity analysis confirms this since small percentage changes in the amount of this parameter within the refrigerator recycling project significantly affect the CBA criteria. This is supported by the fact that the reduction of these subsidies by only $1.67 \%$ reduces the refrigerator recycling project to the limit of acceptability within the financial analysis. Car recycling is, therefore, less dependent on financial assistance in the form of subsidies, which the sensitivity analysis confirms since the reduction of this parameter cannot call into question the acceptability of the project.

The most significant contribution of this paper is reflected in pointing out the role of state subsidies in defining the optimal model of sustainable investment, especially in the field of e-waste recycling. A significant role of state subsidies is already mentioned in many papers that are dealing with sustainable investments, but unlike developed countries that have a long tradition in recycling and stronger institutions, in this particular case, current projects are observed in one post-transitional ambiance, in a developing country which has a specific business environment itself. Low level of citizens' awareness of environmental problems in developing countries further emphasizes the role of the state even more than it is the case in developed countries. Furthermore, we can consider the role of the state as crucial in developing countries, since it plays a leading role in the recycling industry development. On the other hand, due to the high level of human awareness for environmental problems, lower environmental pressure, and many self-regulated mechanisms for preventing pollution, the state plays an important, but more supporting role in developed countries.

The state's role in the form of financial subsidies for the development of the recycling industry in developing countries can be observed in one wider context. Due to the low level of individuals' income in developing countries, there is a greater potential for the motivation of all economic actors to adopt positive environmental norms while gaining financial benefits at the same time. That is the reason why the amount of recycled e-products has increased more than five times during just five years in the Republic of Serbia. State support is important in the field of recycling in general, but it is necessary to distinguish that it is not equally important for both, developing and developed countries.

The significance of the selling price of secondary raw materials as well as the social cost of $\mathrm{CO}_{2}$ gas emissions is smaller, but the sensitivity analysis indicates that changes in these parameters also have an evident impact on the CBA criteria. The paper also points out that traditional financial analysis is not sufficient to evaluate the full effect of the recycling process. Thus, the assessment of these projects by performing economic analysis is a necessity. Economic policy-makers are partially aware of the importance of the recycling process, especially in developing countries such as the Republic of Serbia, where the pressure in the field of waste generation is particularly pronounced. This paper additionally points out to the creators of economic policy, the necessity of greater investment in this area due to the generation of a significant amount of socio-economic benefits in both recycling projects. Stronger state support and generally more stable business conditions would contribute to the development of the recycling industry in the long run and significantly facilitate the work of managers in companies in this sector. Financial stability is very important as it enables the liquidity of all economic entities in the recycling industry and, in the long run, contributes to the continuous improvement of the waste management system through a gradual increase in the number of recycled products.

The market of the Republic of Serbia is an example of a transition economy, but the conclusion drawn from the analysis of the recycling process in this area is a good starting point and can be applied to other developing markets. A serious problem for all developing countries is that there is a huge imbalance between the necessary amount of funds for the development of the recycling industry and the real possibilities of those countries meeting these requirements. Specifically, large and highly developed countries export most of all products that are partially or completely worn out to less developed countries where they are in use for a very short time and then enter the recycling cycle. This is especially true for used cars and all types of e-products. In less developed countries, all these products are recycled in a very short time, which requires significant financial resources in order to carry out the entire process in accordance with regulations. In this way, highly developed 
countries, although they have much greater financial power, direct these funds to the development of new products, and highly responsible countries in terms of ecology, export their "waste" to less developed countries that are not able to adequately bear that pressure on the environment due to lack of funds.

The key limitations in defining the optimal package of sustainable investment arise from the basic characteristics of the recycling process. The group of e-devices is very heterogeneous and includes as many as 10 categories within which there are also many different e-products. This analysis of sustainable investment relies on the analysis of refrigerators that are only one part of WEEE. A more comprehensive analysis would provide a more complete picture of recycling, as it would include more types of e-devices, but at the same time reduce the expressive power of the results thus obtained. Significant changes are expected in the field of car recycling as well. The current model for recycling in this paper relies on the traditional construction of vehicles. However, a significant part of the current car models uses hybrid drive units or are completely transformed into electric models, and they are also potential vehicles for recycling. At the same time, this means that the share of hazardous substances such as batteries and other electrical equipment in cars is significantly increasing, which is also a limitation of the research.

The big challenge in defining the optimal package of investment in recycling lies in the very definition of worn-out devices that enter the recycling process, both on the ELV side and on the WEEE side. In order to meet the growing demand, both in terms of number and the specific characteristics that these devices need to have to meet the increasing demands of customers, this requires certain changes in the design. In the future, significant changes in the construction of these products are expected, so traditional materials are replaced by more modern ones, which significantly affects the structure of potential revenues from the sale of recycled raw materials. Modern tendencies impose the use of the rare metals that pose a great challenge for both producers and recyclers. The current model is a good starting point for further improvement, since creating an optimal waste management model is a major challenge for these two recycling areas.

Finally, one of the important limitations of the study is related to the assumption concerning $\mathrm{CO}_{2}$ pricing. The study has accepted the methodology of evaluation of externality using a $\mathrm{CO}_{2}$-equivalent unit cost suggested by the EU Commission [34]. This is an important limitation of the study, taking into account the stochastic character of the $\mathrm{CO}_{2}$ price and the need for determining an adequate price on GHG emissions for properly assessing the cost of climate change in the project evaluation process and in setting economic incentives for sustainable development. The use of real options emerges as one possible direction of future research to deal with the challenges concerning $\mathrm{CO}_{2}$ pricing [64].

Keeping in mind the above limitations, we believe that our future research should be focused on creating a model of sustainable investment in recycling based on the analysis of not only sufficient conditions or factors but also the necessary conditions, that is, factors that must exist, as recommended in many studies of the Necessary Condition Analysis (NCA) [65,66]. The model created in this way should certainly enable the simultaneous assessment of the direct or indirect effects of both necessary and sufficient conditions, that is, factors for sustainable investments, using the Partial Least Squares Structural Equation Modeling logic (PLS-SEM) [67-69]. Finally, the idea of the combined use of PLS-SEM and NCA as a tool, which should enable researchers to explore and validate hypotheses following a sufficiency logic, as well as hypotheses drawing on a necessity logic [70] would give a new contribution to the theory and practice of sustainable investments in recycling.

Supplementary Materials: The following are available online at http:/www.mdpi.com/2071-1050/12/19/7995/ s1, Table S1. Projected income statement for Financial CBA for End-of-Life Vehicles recycling center-Data used for calculation of CBA criteria; Table S2. Economic flow of the project End-of-Life Vehicles recycling center-Data used for calculation of CBA criteria; Table S3. Projected income statement for refrigerator recycling center-Data used for calculation of CBA criteria; Table S4. The economic flow of the project refrigerator recycling-Data used for calculation of CBA criteria; Table S5. Projected income statement for End-of-Life Vehicles recycling center-Socio-economic CBA-Data used for calculation of CBA criteria; Table S6. The socio-economic flow of the project ELV recycling-Data used for calculation of CBA criteria; Table S7. Projected income statement for refrigerator recycling center-Socio-economic CBA-Data used for calculation of CBA criteria; 
Table S8. The socio-economic flow of the project refrigerator recycling-Data used for calculation of CBA criteria. The sensitivity analysis performed in Tables 9 and 10 in this paper is a product of the application of Excel's Goal Seek analysis to the data from Tables S1-S8.

Author Contributions: Conceptualization, K.D.-M., M.K., and D.S.; literature review, D.S.; materials, M.K.; methodology, K.D.-M., M.K., and D.S.; formal analysis and discussion, K.D.-M. and M.K.; writing-original draft preparation, M.K.; writing-review and editing, K.D.-M. and D.S. All authors have read and agreed to the published version of the manuscript.

Funding: This research received no external funding.

Acknowledgments: The authors are grateful to the anonymous reviewers.

Conflicts of Interest: The authors declare no conflict of interest.

\section{References}

1. Social Investment Forum Foundation. The Mission in the Marketplace: How Responsible Investing Can Strengthen the Fiduciary Oversight of Foundation Endowments and Enhance Philanthropic Missions. 2007. Available online: https://community-wealth.org/sites/clone.community-wealth.org/files/downloads/paperhumphreys.pdf (accessed on 20 April 2020).

2. Camilleri, M.A. Socially Responsible and Sustainable Investing. In Corporate Sustainability, Social Responsibility and Environmental Management; Springer: Cham, Switzerland, 2007; pp. 61-77. [CrossRef]

3. Desmadryl, X. SRI \& ESG Inclusion: Does It Pay After All? Presented at ANBID/UNEP FI Roundtable: Private Banking and Sustainable Investment in Emerging Economies, São Paolo, 23 March 2017. Available online: https://www.unepfi.org/fileadmin/events/2007/saopaulo/desmadryl.pdf (accessed on 15 June 2020).

4. Elkington, J. Towards the sustainable corporation: Win-win-win business strategies for sustainable development. Calif. Manag. Rev. 1994, 36, 90-100. [CrossRef]

5. Geczy, C.C.; Stambaugh, R.F.; Levin, D. Investing in Socially Responsible Mutual Funds; Working Paper; The Wharton School University of Pennsylvania: Philadelphia, PA, USA, 2005. [CrossRef]

6. Eursif. European SRI Study 2018. Available online: http://www.eurosif.org/wp-content/uploads/2018/11/ European-SRI-2018-Study.pdf (accessed on 15 June 2020).

7. US SIF. Report on US Sustainable, Responsible and Impact Investing Trends. 2018. Available online: https: //www.ussif.org/files/US\%20SIF\%20Trends\%20Report\%202018\%20Release.pdf (accessed on 15 June 2020).

8. Palma-Ruiz, J.M.; Castillo-Apraiz, J.; Gómez-Martínez, R. Socially Responsible Investing as a Competitive Strategy for Trading Companies in Times of Upheaval Amid COVID-19: Evidence from Spain. Int. J. Financ. Stud. 2020, 8, 41. [CrossRef]

9. WRME. Waste and Recycling Middle East (WRME), Special Supplement: Auto Recycling, 2014/2015. Available online: http://waste-recyclingme.ae/WR\%20-Suppliment\%202014-15.pdf (accessed on 21 April 2020).

10. Simic, V. End-Of-Life Vehicle Recycling-A Review of the State-Of-The-Art. Tehn. Vjesn. 2013, 20, 371-380. Available online: https://hrcak.srce.hr/file/147734 (accessed on 12 April 2020).

11. Schwarzer, S.; Bono, A.D.; Peduzzi, P.; Giuliani, G.; Kluser, S. E-Waste, the Hidden Side of IT Equipment's Manufacturing and Use. United Nations Environment Program, Environment Alert Bulletin No. 5, Switzerland. 2005. Available online: https://archive-ouverte.unige.ch/unige:23132 (accessed on 12 April 2020).

12. Baldé, C.P.; Forti, V.; Kuehr, R.; Stegmann, P. The Global E-Waste Monitor-2017. United Nations University (UNU), International Telecommunication Union (ITU) \& International Solid Waste Association (ISWA), Bonn/Geneva/Vienna. 2017. Available online: https:/collections.unu.edu/eserv/UNU:6341/Global-E-waste_ Monitor_2017_electronic_single_pages_.pdf (accessed on 14 April 2020).

13. Parajuly, K. Circular Economy in E-waste Management: Resource Recovery and Design for End-Of-Life. Ph.D. Thesis, University of Southern Denmark, Odense, Denmark, 2017. Available online: https://portal. findresearcher.sdu.dk/files/124947551/PhD_Thesis_Parajuly_2017_003_.pdf (accessed on 9 April 2020).

14. Parajuly, K.; Kuehr, R.; Awasthi, A.K.; Fitzpatrick, C.; Lepawsky, J.; Smith, E.; Widmer, R.; Zeng, X. Future E-Waste Scenarios, StEP (Bonn). UNU ViE-SCYCLE (Bonn) \& UNEP IETC (Osaka). 2019. Available online: https://www.step-initiative.org/files/_documents/publications/FUTURE\%20E-WASTE\% 20SCENARIOS_UNU_190829_low_screen.pdf (accessed on 9 April 2020).

15. Rosa, P.; Terezi, S. Improving end of life vehicle's management practices: An economic assessment through system dynamics. J. Clean. Prod. 2018, 184, 520-536. [CrossRef] 
16. Andersson, M.; Söderman, M.L.; Sandén, B. Adoption of Systemic and Socio-Technical Perspectives in Waste Management, WEEE and ELV Research. Sustainability 2019, 11, 1677. [CrossRef]

17. Karagoz, S.; Aydin, N.; Simic, V. End-of-life vehicle management: A comprehensive review. J. Mater. Cycles Waste Manag. 2020, 22, 416-442.

18. Schmid, A.; Batton-Hubert, M.; Naquin, P.; Gourdon, R. Multi-Criteria Evaluation of End-of-Life Vehicles' Dismantling Scenarios with Respect to Technical Performance and Sustainability Issues. Resources 2016, 5, 42. [CrossRef]

19. Fonseca, A.S.; Nunes, M.I.; Matos, M.A.; Gomes, A.P. Environmental impacts of end-of-life vehicles' management: Recovery versus elimination. Int. J. Life Cycle Assess 2013, 18, 1374-1385. [CrossRef]

20. Santini, A.; Morselli, L.; Passarini, F.; Vassura, I.; Di Carlo, S.; Bonino, F. End-of-Life Vehicles management: Italian material and energy recovery efficiency. Waste Manag. 2011, 31, 489-494. [CrossRef]

21. Tian, J.; Chen, M. Assessing the economics of processing end-of-life vehicles through manual dismantling. Waste Manag. 2016, 56, 384-395. [CrossRef]

22. Raja Mamat, T.N.A.; Mat Saman, M.Z.; Sharif, S.; Simic, V.; Abd Wahab, D. Development of a performance evaluation tool for end-of-life vehicle management system implementation using the analytic hierarchy process. Waste Manag. Res. 2018, 36, 1210-1222. [CrossRef] [PubMed]

23. Bellmann, K.; Khare, A. Economic issues in recycling end-of-life vehicles. Technovation 2000, 20, 677-690. [CrossRef]

24. Rovinaru, F.I.; Rovinaru, M.D.; Rus, A.V. The Economic and Ecological Impacts of Dismantling End-of-Life Vehicles in Romania. Sustainability 2019, 11, 6446. [CrossRef]

25. Marshall, R.E.; Farahbakhsh, K. Systems approaches to integrated solid waste management in developing countries. Waste Manag. 2013, 33, 988-1003. [CrossRef] [PubMed]

26. Allesch, A.; Brunner, P.H. Assessment methods for solid waste management: A literature review. Waste Manag. Res. 2014, 32, 461-473. [CrossRef] [PubMed]

27. Liu, H.; Wu, X.; Dou, D.; Tang, X.; Leong, G.K. Determining Recycling Fees and Subsidies in China's WEEE Disposal Fund with Formal and Informal Sectors. Sustainability 2018, 10, 2979. [CrossRef]

28. Gu, Y.; Wu, Y.; Xu, M.; Mu, X.; Zuo, T. Waste electrical and electronic equipment (WEEE) recycling for a sustainable resource supply in the electronics industry in China. J. Clean. Prod. 2016, 127, 331-338. [CrossRef]

29. Wäger, P.A.; Hischier, R.; Eugster, M. Environmental impacts of the Swiss collection and recovery systems for Waste Electrical and Electronic Equipment (WEEE): A follow-up. Sci. Total Environ. 2011, 409, 1746-1756. [CrossRef]

30. Hischier, R.; Wäger, P.; Gauglhofer, J. Does WEEE recycling make sense from an environmental perspective? The environmental impacts of the Swiss take-back and recycling systems for waste electrical and electronic equipment (WEEE). Environ. Impact Assess. Rev. 2005, 25, 525-539. [CrossRef]

31. Cucchiella, F.; D'Adamo, I.; Lenny Koh, S.C.; Rosa, P. Recycling of WEEEs: An economic assessment of present and future e-waste streams. Renew. Sust. Energy Rev. 2015, 51, 263-272. [CrossRef]

32. Parajuly, K.; Wenzel, H. Potential for circular economy in household WEEE management. J. Clean. Prod. 2017, 151, 272-285. [CrossRef]

33. Xue, M.; Xu, Z. Application of Life Cycle Assessment on Electronic Waste Management: A Review. Environ. Manag. 2017, 59, 693-707. [CrossRef] [PubMed]

34. European Commission. Guide to Cost Benefit Analysis of Investment Projects; European Commission: Brussels, Belgium, 2014; Available online: https://ec.europa.eu/regional_policy/sources/docgener/studies/pdf/cba_ guide.pdf (accessed on 17 April 2020).

35. Hu, S.; Wen, Z. Why does the informal sector of end-of-life vehicle treatment thrive? A case study of China and lessons for developing countries in motorization process. Resour. Conserv. Recycl. 2015, 95, 91-99. [CrossRef]

36. Xia, X.; Li, J.; Tian, H.; Zhou, Z.; Li, H.; Tian, G.; Chu, J. The construction and cost-benefit analysis of end-of-life vehicle disassembly plant: A typical case in China. Clean Technol. Environ. Policy 2016, 18, 2663-2675. [CrossRef]

37. Lin, H.-T.; Nakajima, K.; Yamasue, E.; Ishihara, K.N. Recycling of End-of-Life Vehicles in Small Islands: The Case of Kinmen, Taiwan. Sustainability 2018, 10, 4377. [CrossRef]

38. Chen, Z.; Chen, D.; Wang, T.; Hu, S. Policies on end-of-life passenger cars in China: Dynamic modeling and cost-benefit analysis. J. Clean. Prod. 2015, 108, 1140-1148. [CrossRef] 
39. Farel, R.; Yannou, B.; Ghaffari, A.; Leroy, Y. A cost and benefit analysis of future end-of-life vehicle glazing recycling in France: A systematic approach. Resour. Conserv. Recycl. 2013, 74, 54-65. [CrossRef]

40. Gurita, N.; Bongaerts, J.C.; Cost-benefit analysis of WEEE Recycling in Germany Case study of mobile phones and smartphones. Presented at the World Resources Forum-'Boosting Resource Productivity by adopting the Circular Economy', Davos, Switzerland. October 2015. Available online: http://www.wrforum. org/wp-content/uploads/2015/10/SS9-Gurita-new.pdf (accessed on 12 April 2020).

41. Zadmehr, Q.; Ebrahimi, A.A.; Askari, R.; Dehghani, A.; Mokhtari, M. Quantitative and Qualitative Study on Electric and Electronic Waste and Economic Evaluation of Their Collection and Recycling by Using the Cost-benefit Model: A Case Study in Dezful City, 2017. J. Environ. Health Sustain. Dev. 2018, 3, 518-530. Available online: http://jehsd.ssu.ac.ir/article-1-119-en.html (accessed on 12 April 2020).

42. Rigamonti, L.; Falbo, A.; Zampori, L.; Sala, S. Supporting a transition towards sustainable circular economy: Sensitivity analysis for the interpretation of LCA for the recovery of electric and electronic waste. Int. J. Life Cycle Assess 2017, 22, 1278-1287. [CrossRef]

43. D'Adamo, I.; Rosa, P.; Terzi, S. Challenges in Waste Electrical and Electronic Equipment Management: A Profitability Assessment in Three European Countries. Sustainability 2016, 8, 633. [CrossRef]

44. Wan, Z.; Liu, J.; Zhang, J. Nonlinear optimization to management problems of end-of-life vehicles with environmental protection awareness and damaged/aging degrees. J. Ind. Manag. Optim. 2020, 16, 2117-2139. [CrossRef]

45. Zhou, F.; Lin, Y.; Wang, X.; Zhou, L.; He, Y. ELV Recycling Service Provider Selection Using the Hybrid MCDM Method: A Case Application in China. Sustainability 2016, 8, 482. [CrossRef]

46. Djordjević, L.; Radovanović, N.; Redžić, N.; Jovanović, G. Waste Management in the Republic of Serbia in the Period from 2011 to 2018. Environmental Protection Agency of the Republic of Serbia. 2019. Available online: http://www.sepa.gov.rs/download/Otpad_2011_2018.pdf (accessed on 10 May 2020). (In Serbian)

47. Ratković, B.; Simić, V.; Vidović, M. Neuro-fuzzy approach in estimating the number of ELVs in Serbia. In Proceedings of the XXXV Symposium on Operational Research (SYM-OP-IS 2008), Soko Banja, Serbia, 14-17 September 2008; pp. 323-326. (In Serbian). [CrossRef]

48. Pavlović, A. Doprinos Integrisanog Modela Upravljanja Motornim Vozilima na Kraju Životnog Ciklusa Razvoju Razvoju Republike Srbije [The Contribution of an Integrated Model of Motor Vehicle Management at the End of the Life Cycle To The Development of the Republic of Serbia]. Ph.D. Thesis, Technical Faculty 'Mihajlo Pupin', University of Novi Sad, Zrenjanin, Serbia, 2016.

49. Knežević, G.; Pavlović, V. CSR reporting practice: Is there room for integration?-Evidence from Serbian foreign investors. J. East Eur. Manag. Stud. 2019, 24, 280-304. [CrossRef]

50. The Ministry of Environmental Protection of the Republic of Serbia. Pravilnik o u Uskladjenim Iznosima Podsticajnih Sredstava za Ponovnu Upotrebu, Reciklažu i Korišćenje Određenih Vrsta Otpada [Rules on Harmonized Amounts of Incentives for Reuse, Recycling and Use of Certain Types of Waste]; Službeni Glasnik RS: Belgrade, Serbia, 2020.

51. The Ministry of Environmental Protection of the Republic of Serbia. Pravilnik o Usklađenim Iznosima Naknade za Upravljanje Posebnim Tokovima Otpada [Rules on the Harmonized Amount of Compensation for the Management of Specific Waste Streams]; Službeni Glasnik RS: Belgrade, Serbia, 2018.

52. The European Parliament and the Council of the European Union. Directive 2012/19EU on Waste from Electrical and Electronic Equipement WEEE. 2012. Available online: https://eur-lex.europa.eu/legal-content/ EN/TXT/PDF/?uri=CELEX:32012L0019\&from=EN (accessed on 20 April 2020).

53. Grubor, S.; Milivojević, J.; Kokić Arsić, A. Tržište motornih vozila na kraju životnog ciklusa u funkciji kvaliteta života [The end-of-life motor vehicle market as a function of quality of life]. In Proceedings of the Conference 'Quality Festival 2009', Kragujevac, Serbia, 20-22 May 2009; pp. 112-118.

54. Kozić, A.; Sudarević, D. Pristup recikliranju motornih vozila [Approach to motor vehicle recycling]. In Proceedings of the Conference 'Quality Festival 2005', Kragujevac, Serbia, 19-21 May 2005; pp. H20-H28.

55. Milutinović, B.; Stefanović, G.; Ilic, M.; Jocić, D. Cost benefit analysis of electronic waste recycling. In Proceedings of the 2nd International Conference, Mechanical Engeneering in XXI Century, Faculty of Mechanical Engineering, Niš, Serbia, 20-21 June 2013; pp. 199-202.

56. Krstić, M. Ocena Opravdanosti Investicija u Reciklažu-Izazovi za Upravljanje Održivim Razvojem u Republici Srbiji [Evaluation of Investments in Waste Recycling-Challenges for Sustainable Development Management in the Republic of Serbia]. Ph.D. Thesis, University of Niš, Niš, Serbia, 2019. 
57. Cumbul Altaya, M.; Sivri, N.; Onat, B.; Sahin, U.; Zoraga, M.; Fatih Altay, H. Recycle of metals for end-of-life vehicles (ELVs) and relation to Kyoto protocol. Renew. Sustain. Energy Rev. 2011, 15, 2447-2451. [CrossRef]

58. Electric Power Industry of Serbia. Production Capacity. Available online: http://www.eps.rs/eng/Pages/ Kapaciteti-ElEn.aspx (accessed on 21 April 2020).

59. Foelster, A.-S.; Andrew, S.; Kroeqer, L.; Bohr, P.; Dettmer, T.; Boehme, S.; Herrmann, C. Electronic recycling as an energy efficiency measure-A Life Cycle Assesment (LCA) study on refrigerator recycling in Brazil. J. Clean. Prod. 2016, 129, 30-42. [CrossRef]

60. Hiratsuka, J.; Sato, N.; Yoshida, H. Current status and future perspectives in end-of-life vehicle recycling in Japan. J. Mater. Cycles Waste Manag. 2014, 16, 21-30. [CrossRef]

61. Yu, L.; He, W.; Li, G.; Huang, J.; Zhu, H. The development of WEEE management and effects of the fund policy for subsidizing WEEE treating in China. Waste Manag. 2014, 34, 1705-1714. [CrossRef]

62. Menikpura, S.N.M.; Hotta, Y.; Santo, A.; Jain, A. Socio-economic and environmental attributes of Waste Electrical and Electronic Equipment (WEEE) recycling in Asia. MIJST 2016, 2, 183-199. [CrossRef]

63. Krstić, M.; Denčić-Mihajlov, K. Waste electrical \& electronic equipment recycling: Socioeconomic and institutional challenges for sustainable growth in Serbia. In Proceedings of the 9th International Conference Sustainable Growth in Small Open Economies, Institute of Economic Science, Belgrade, Serbia, 26 October 2017; pp. 64-67.

64. Deeney, P.; Cummins, M.; Heintz, K.; Pryce, V. A real options based decision support tool for R\&D investment: Application to $\mathrm{CO}_{2}$ recycling technology. Eur. J. Oper. Res. 2020, in press, corrected proof. [CrossRef]

65. Dul, J. Necessary Condition Analysis (NCA): Logic and Methodology of "Necessary but Not Sufficient" Causality. Organ. Res. Methods 2016, 19, 10-52. [CrossRef]

66. Dul, J.; Hak, T.; Goertz, G.; Voss, C. Necessary condition hypotheses in operations management. Int. J. Oper. Prod. Manag. 2010, 30, 1170-1190. [CrossRef]

67. Hair, J.F.; Risher, J.J.; Sarstedt, M.; Ringle, C.M. When to use and how to report the results of PLS-SEM. EBR 2019, 31, 2-24. [CrossRef]

68. Manley, S.C.; Hair, J.F., Jr.; Williams, R.I., Jr.; McDowell, W.C. Essential new PLS-SEM analysis methods for your entrepreneurship analytical toolbox. Int. Entrep. Manag. J. 2020. ahead-of-print. [CrossRef]

69. Marin-Garcia, J.; Alfalla-Luque, R. Key issues on Partial Least Squares (PLS) in operations management research: A guide to submissions. J. Ind. Eng. Manag. 2019, 12, 219-240. [CrossRef]

70. Richter, N.F.; Schubring, S.; Hauff, S.; Ringle, C.M.; Sarstedt, M. When predictors of outcomes are necessary: Guidelines for the combined use of PLS-SEM and NCA. Ind. Manag. Data Syst. 2020. ahead-of-print. [CrossRef]

(C) 2020 by the authors. Licensee MDPI, Basel, Switzerland. This article is an open access article distributed under the terms and conditions of the Creative Commons Attribution (CC BY) license (http://creativecommons.org/licenses/by/4.0/). 